\title{
Investigating the mediating role of market orientation between internal marketing and the development of entrepreneurial orientation within private sports clubs
}

Mediating role of market orientation

\author{
Hossein Mansouri and Saeed Sadeghi Boroujerdi \\ University of Kurdistan, Sanandaj, Iran \\ Michael Polonsky \\ Deakin University, Victoria, Australia \\ Maizaitulaidawati Md Husin \\ Universiti Teknologi Malaysia, Kuala Lumpur, Malaysia and \\ Universiti of Business and Technology, Jeddah, Saudi Arabia, and \\ Mehdi Seydi \\ University of Kurdistan, Sanandaj, Iran
}

\begin{abstract}
Purpose - This study examines the role of market orientation in the relationship between internal marketing and entrepreneurial orientation within private sports clubs.

Design/methodology/approach - The research is a descriptive-correlational study based on private sports clubs employees within Iran (Sanandaj). A theoretical model was developed based on the literature and tested using SPSS and PLS-SEM software.

Findings - The findings indicate a positive relationship between internal marketing and employees' entrepreneurial orientation. Market orientation has also played a positive mediating role in the relationship between internal marketing and entrepreneurial orientation.

Originality/value - The results suggest a higher level of market orientation in the organization can increase teamwork and, consequently, entrepreneurship development among employees. This is important in sports clubs as employees have a significant role in the success of the sports club. Club employees' satisfaction, generated through internal marketing, provides is a prerequisite for customer satisfaction. This therefore creates an environment supportive of entrepreneurial orientation in the club.
\end{abstract}

Keywords Internal marketing, Market orientation, Entrepreneurship development, Sports club

Paper type Research paper

\section{Introduction}

Having an entrepreneurial orientation in the field of sports is very important because there are many opportunities for economic value creation and the opportunity to increase economic performance, especially in Iran where two-thirds of the population are young adults (18-35 [1]), with many not actively participating in sport (Mohamadkazemi et al., 2014). Additionally,

(C) Hossein Mansouri, Saeed Sadeghi Boroujerdi, Michael Polonsky, Maizaitulaidawati Md Husin and Mehdi Seydi. Published in New England Journal of Entrepreneurship. Published by Emerald Publishing Limited. This article is published under the Creative Commons Attribution (CC BY 4.0) license. Anyone may reproduce, distribute, translate and create derivative works of this article (for both commercial and non-commercial purposes), subject to full attribution to the original publication and authors. The full terms of this license may be seen at http://creativecommons.org/licences/by/4.0/legalcode

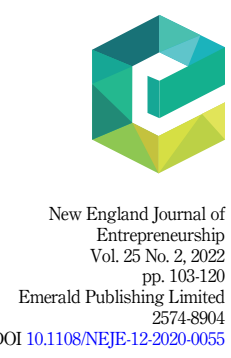


NEJE

25,2

104

the number of physical education graduates is enormous, suggesting that these new graduates can help grow the sports field. Entrepreneurial orientation is one of the most wellknown theories in entrepreneurial and managerial research (Pittino et al., 2017). It includes decision-making styles, processes and methods that shape a company's entrepreneurial activities (Lumpkin and Dess, 1996). Entrepreneurial orientation is a set of distinct but interrelated behaviors that contain aspects of innovation, leadership, aggressive competition, risk-taking and independence (Pearce et al., 2010) and is essential for a wide range of for-profit and non-profit organizational settings, including the sports domain (Seyed Javadin et al., 2014).

Small and medium-sized businesses have more flexibility and can adapt to rapid environmental changes and react faster than large firms Jakubiak and Chrapowicki (2018) and, as such, are often more entrepreneurial. Kao (1993) defined entrepreneurship as "a process of making changes; doing something different, thus creating wealth for the individual and adding value to society." In this changing business environments with evolving customer needs, adaption is vital in small organizations. This means that small organizations, such as sports clubs, have to perform and adapt to these dynamic changing environments. Succeeding in such a challenging market requires responding consciously and quickly to both the market and customers. Therefore, the business has to have a thorough understanding of the competitive environment in which they work in and being marketorientated is critical in such dynamic times.

Marketing theory has evolved from the production orientation where firms increased efficiency, assuming consumers would purchase goods there were well made and reasonably priced (Kushwaha and Dubey, 2018), ultimately to firms' having a market orientation where they focus was on producing goods and services that most effectively met customers wants and needs. Thus, the market orientation approach focuses on gathering information about customers' needs and requests and competitors' capabilities, which leads to creating more value for customers by using the organizations' resources (Awwad and Agti, 2011) and is essential for sports organizations who need to be highly responsive to members (Zheng-lun, 2008). Market orientation is essential for entrepreneurial companies as it leads to learning, environmental adaptation, rapid response to environmental opportunities and threats (Ma et al., 2012). Market orientation is also one of the most effective and efficient types of organizational culture, creating superior value for customers enabling business success (Herman et al., 2018).

Market orientation includes a set of beliefs that put customers in the spotlight to ensure the company's long-term profitability. It also emphasizes creating an effective and efficient business to produce the highest value for the customer and competitive advantage (Tsai and Tang, 2008). In market orientation, customers are prioritized so that market orientation is the cornerstone of marketing. (Ericsson, 2015). Lam et al. (2010) suggest that market orientation is considered a social learning process through which market orientation can be acquired and transmitted at the individual employee level. A market-oriented organization can better identify the needs and demands of the target market. As a result, it can achieve customer satisfaction more efficiently and effectively than other competitors can. Thus, a marketoriented organization can achieve the organization's goals, such as market share and higher profits, compared with an organization that engages in less market-oriented activities (Tsiotsou, 2010). Market orientation also has a special place in sports-related organizations today (Fadda, 2020; Zheng-lun, 2008). Farrelly et al. (2008) state that sports organizations need to understand better customer needs and competitors' performance due to changing customer requirements and increasing competitors. Thus being market orientation contributes to sports organization's success.

Sports clubs are private associations whose objectives include promoting and developing interest in a particular sport or physical activity, their members' participation in these 
activities and organizations, and participation in competitions. Sports clubs are also commonly associated with health club. Ng (2009) states that companies, organizations and sports clubs should increase the quality of goods and services provided to customers, with a customer-focused set of actions and beliefs. Thus, sports clubs are service organizations, as their core offering is intangible, even though they may require equipment and infrastructure to deliver these services. For service organizations, managing internal, external, and interactive marketing is essential. While internal marketing focus to meeting the needs of customers. Internal marketing promotes a company's objectives to employees within the organization. On the other hand, interactive marketing is a marketing strategy that uses twoway communication channels to allow customers to connect with a company directly (Eric, 2017).

As with any service setting, the employees play a central role in attracting, building and maintaining customer relationships. Research suggests that internal marketing is essential for ensuring that employees deliver or organizational promises and are the interface between customers and organizations (Tansuhaj et al., 1988; Huang, 2020). Internal marketing was initially proposed as a single dimension to encourage employees to deliver on customerfocused goals, where the audience is the firms' employees (Welch and Jackson, 2007). Today, internal marketing studies have a common theme and internal marketing has been expanded to comprise several dimensions (Huang and Rundle-Thiele, 2015; Tsai and Tang, 2008), including Production of internal information, Dissemination of internal information, Responding to the domestic market. One of the most comprehensive definitions of internal marketing was provided by Rafiq and Ahmed (2000), in which internal marketing has been introduced as a planned effort using an approach such as marketing to overcome organizational resistance to change and balance, motivating and coordinating between tasks as well as integrating employees to implement effective corporate strategies as well as a task to create customer satisfaction through the process of forming motivated and customeroriented employees (e.g. Ahmed and Rafiq, 2003; Grönroos and Helle, 2010; Yusuf et al., 2016).

\section{The research context}

Today, sport has a wide influence on society. It plays a role in people's health, creating healthy leisure time, physical activity, pleasure, healthy relationships, especially in the younger generation (Seyed Javadin et al., 2014). Most of the early research on market orientation has been in domains other than sports (e.g. Agti and Louafi, 2019; Huang and Rundle-Thiele, 2015; Ismail et al., 2018; Tsiotsou, 2010), even though work is the sports domain exists (e.g. Zheng-lun, 2008), yet sports organizations are highly market-oriented (Mondalizadeh, 2019).

A sports club is a collection of individuals that provides entertainment, competition and training in sports-related activities. Therefore, sports clubs can have various goals for different segments, including training, developing individual potential, improving fitness, physical and mental capabilities, creating space for social interactions and communication, and competition between people. A sports club is an institution that is run to educate and enhance individuals' physical and spiritual strength. In other words, sports clubs operate to maintain health and members' physical and mental activity, where athletes of varying abilities get together to exercise for health and wellness (Ghorbani and Safari, 2017). There was no agreed definition of a sports club (Vamplew, 2013). However, Vamplew (2013) mentioned that all sports clubs include activities involving playing and/or watching sport at a recreational and/or competitive level. Sports clubs have individuals responsible for administrative and offers a formal membership that gives its members playing facilities (Vamplew, 2013).

According to the Iranian Statistics Centre's latest report, in 2019, more than $51 \%$ of Iranians play sports, which is up from $44 \%$ in 2015. Private sports clubs are therefore
Mediating role of market orientation 
NEJE

25,2

106

essential. These clubs create jobs and lead to entrepreneurial activities within the sector by club managers and coaches seeking to identify new ways to address the market's needs. Thus, this study explores how internal marketing and market orientation enhance sports clubs' entrepreneurial orientation within private sports clubs. Besides, it examines how internal marketing can increase the organization's employees' entrepreneurial spirit and lead these clubs to more entrepreneurial activities and the mediating role of market orientation in these relationships. No previous research has been conducted on these issues within a sports context, and indeed, none has been undertaken in Iran. As will be discussed below, these issues have been examined in a range of non-sports contexts.

\section{Literature review \\ Internal marketing and entrepreneurial orientation}

With advancements in innovation, organizations must be familiar with how to compete in these dynamic environments (Zhang et al., 2020). Internal marketing highlights marketing activities to employees in the organization. According to marketing theories, internal marketing emphasizes the importance of the employees' satisfaction and views their jobs as internal products. The goal of internal marketing is the development and motivation of staff. Internal marketing's function is based on the supposition that motivated employees comply with organizational policies and decision-making. This benefits the organization as employees understand organizational goals, empowering employees to act, fulfil their roles and implement changes. Therefore, these engaged employees can advance innovation and organizational changes (Jalilvand et al., 2019). Internal marketing recognized employees' value, empowering personnel, leading to innovation and entrepreneurship within the organization (De Bruin et al., 2021). Internal marketing enhances the staff's motivation and helps to enhance their human and social capital. As the staff's motivation increase, the company will better achieve strategic renewal and change, transforming the business and innovating, which is essential for having an entrepreneurial orientation. Thus, it can be suggested that there is a positive relationship between internal marketing and entrepreneurial orientation (Subramony et al., 2018). Entrepreneurial orientation is one of the most well-known factors in entrepreneurial and managerial studies (Pittino et al., 2017). This orientation includes decision-making styles, processes, and methods, forming a company's entrepreneurial activities (Lumpkin and Dess, 1996). Entrepreneurship and sports management has more recently received increased attention (González-Benito et al., 2009). For example, Fadda (2020) explore entrepreneurial orientation with a focus on surf sports schools and found that through cooperating and sharing ideas these schools could be more innovative. Keating and Olivare (2007) found that the most crucial factor in entrepreneurship in new-established organizations is addressing the firm's human resources needs. Twomey and Harris (2000) also explained that supporting human resources and their needs encourages employees' career development and entrepreneurial behaviors. Yadav and Bansal (2020), identified that many studies in developing countries had examined entrepreneurship, making it important in both developed and developing country contexts. It is suggested that enhancing entrepreneurship requires internal marketing. For example, Jalilvand et al. (2019) found that internal marketing and entrepreneurship are two drivers of innovation in family careers. Internal marketing was also shown to be the primary determiner of entrepreneurial orientation in family businesses) Jalilvand et al. (2019). Jin et al. (2018) suggested that both entrepreneurship and competing in their internal market require companies to augment technological and marketing abilities. These factors also result in a rise in organizational performance (Jin and Cho, 2018). Furthermore, the integration of technology and marketing capabilities has been confirmed to influence entrepreneurial eagerness and export operation Ultimately, past works' results identify that aspects of 
entrepreneurial keenness impact firms' and sports organizations' marketing ability. They also supported the fact that marketing ability affects performance, and it has an impact on entrepreneurial orientation.

Therefore, it is posited that:

H1. Internal marketing has a positive effect on the development of entrepreneurial orientation in private sports clubs.

\section{Internal marketing and market orientation}

Market orientation includes a set of beliefs that put customers in the spotlight to achieve longterm profitability. Market orientation also emphasizes having an effective and efficient business to create the highest value for the customer and gain a competitive advantage (Tsai and Tang, 2008). A host of definitions have been offered for market orientation in the literature. Narver and Slater (1990) presented an initial measure of market orientation that included three behavioral factors (customer orientation, competitor orientation and performance coordination) and two decision criteria (sustainability and long-term profitability). Kohli and Jaworski (1990) introduced a measure of market orientation from a behavioral and process perspective, suggesting it incorporated; data collection, information transfer, and compilation and conduction of responsive actions. Zhang et al. (2020) found that these two scales of market orientation were reliable in a developing country context. They assessed customer orientation, data collection, coordination, and information implementation rationality and application of the scale. All definitions for market orientation identify that customer satisfaction is the central pillar of the approach, and hence, all organizational activities should focus on being marketing oriented (Herrero et al., 2018). Researches have shown that market orientation is one of the most effective and efficient organizational culture types that shape organizational behaviors, creating superior value for customers (Herman et al., 2018). In addition to that, numerous researchers have suggested that market orientation is a tool for implementing the definition of marketing in the organization (Lado et al., 2013). Thus, it is important for service organizations, including in the sports club domain, to be customer-focused. The sports club needs to be adaptive to the consumers' personalized needs and objectives.

In the service marketing domain, while clients are the ultimate goal, the firm's employees are also essential (Chiu et al., 2019; Cooper and Cronin, 2000). Thus, while market orientation is important for external customers, internal marketing focuses on attracting, developing and motivating the firm's employees, critical for market orientation. In service organizations, employees are at the forefront of customer interfacing activities and play a key role in communicating with customers (Al-Hawary et al., 2013; Tang et al., 2020). It is also believed that internal marketing's success is enhanced when firms are market orientation because market orientation encourages employees to perform better. Employees also feel that the organization is important to them (Gellatly et al., 2020).

Numerous studies have confirmed a relationship between internal marketing and market orientation (Pitt et al., 1996; Swartz, 1990). The results of Gellatly et al. (2020) showed that internal market orientation affects internal marketing. Market orientation and marketing also affect public service motivation. Chuang (2018) proved that market orientation is vital for emarketing systems and facilitates value creation for vendors and customers. Also, the research results by Jin et al. (2018) found that market orientation influences marketing ability and pursuant to it. The firms' marketing ability modulates the relationship between market orientation and performance. According to Kamboj and Rahman (2017), market orientation positively affects all four marketing capabilities. Also, marketing capabilities have a positive effect on innovation, with innovation, in turn, having a positive effect on competitive advantage and company performance. Finally, it has been suggested that internal marketing
Mediating role of market orientation 
NEJE

25,2

has a positive effect on market orientation (Kyriazopoulos et al., 2007; Salehzadeh et al., 2017). Much of the literature suggests that internal marketing activities are the primary tools to ensure employee retention, market orientation, customer satisfaction and profitability.

Therefore, it is suggested:

H2. Internal marketing has a positive effect on market orientation in private sports clubs.

\section{8}

\section{Market orientation and the development of entrepreneurial orientation}

Sports clubs are an essential component of sports systems. In sport, a sports club should make sports more accessible, and therefore clubs should have a broad social mission. Thus, sports clubs are described as potentially desirable environments for sports entrepreneurship. These organizations need to be entrepreneurial, as they need to link themselves with other organizations, associations, governmental policy participants and potential participants. Ensuring organizations and their employees are professional and entrepreneurial is necessary to facilitate the achievement of organizational goals. There are generally few rules regulating the various services and offerings available to consumers within the sports industry, and there are very few barriers to entry and exit to the sector. This means that organizations are continually seeking out new opportunities, and thus they need to have an entrepreneurial orientation, where they are willing to undertake new activities. Thus, entrepreneurship and having an entrepreneurial orientation is applicable in the sports and sports club domain (Fadda, 2020; González-Benito et al., 2009). However, an organization with a high level of entrepreneurial orientation undertakes unique investments in distinctive products or services, with such risky investments potentially jeopardizing the organization's resources (Escamilla-Fajardo et al., 2020). Various authors such as Spilling (1996), Ball (2005) and Fadda (2020) have found that entrepreneurship is important in sport and sports organizations. Hardy and Pope (1996) showed that entrepreneurship provides a unique way to view sport and suggests that further research should explore sport from an entrepreneurial perspective. In addition, Hemme et al. (2017) stated that sport is a rich base for entrepreneurial activities. Sports entrepreneurship has been considered a promising conceptual link between entrepreneurship and sports management research (Frisby, 2005).

Today, market orientation has been the focus of many studies and review articles (Kirca et al., 2005; Kuratko et al., 2005; Liao et al., 2011). Market orientation involves the pursuit of current opportunities, while entrepreneurial orientation is more focused on future opportunities. Many studies have confirmed that these two concepts affect each other (Chen and Hsu, 2013). A majority of research at the organizational level focuses on market orientation leading to dynamic and continuous strategic planning by effectively measuring market orientation (Zhang et al., 2020). On the other hand, the growth of entrepreneurial companies requires that they be focused on market demands. Entrepreneurial orientation improves a company's ability to understand and recognize market opportunities before its competitors, thus gaining a competitive advantage (Acosta et al., 2018). According to the concept of market orientation, a company intends to provide services or products that can meet customers' needs, guaranteeing these services are delivered more effectively and efficiently than competitors. (Ali et al., 2020). Entrepreneurship and have an entrepreneurial orientation are significantly related to market knowledge and adaptation of products and services for consumers' varying needs (Faroque et al., 2021).

Faroque et al. (2021) showed that the impact of entrepreneurial ability on information dissemination and positive response is significant. Likewise, the effect of entrepreneurial ability on customer orientation, intelligence production, dissemination and positive response is crucial. The results also depicted that export market orientation mediates the relationship between entrepreneurial ability and firm performance (Monteiro et al., 2017; Octavia et al., 
2020; Montiel-Campos, 2018), and also explains that entrepreneurship and market orientation have a significant relationship. The results of Morgan and Anokhin (2020) found that larger firms may be more proficient in managing entrepreneurial orientation and market orientation. In contrast, smaller firms, such as sports clubs, maybe less efficient in developing these abilities. Firms focusing on services instead of goods also benefit from the combined impact of market orientation and entrepreneurship. The international performance of these types of job is affected by their network capability and their international entrepreneurial orientation, and the positive effect of international entrepreneurial orientation on network capability and market orientation (Acosta et al., 2018). GonzálezBenito et al. (2009) showed that there is a strong relationship between entrepreneurship and market orientation. Although these tendencies may be implemented separately, companies care about entrepreneurship when they are market-oriented (see Figure 1).

Consequently, the relationship between market orientation and development of entrepreneurial orientation is proposed:

H3. Market orientation has a positive effect on the development of entrepreneurial orientation in private sports clubs.

H4. Market orientation mediates the relationship between internal marketing and the development of entrepreneurial orientation.

\section{Methodology}

The purpose of this study is to identify whether market orientation has a mediating role in the relationship between internal marketing and entrepreneurial orientation within Iranian sports clubs. The research is descriptive-correlational, using PLS-SEM3 to test the proposed relationships, as PLS is often preferred, especially with slightly smaller sample sizes (Hair et al., 2019).

Data were collected from 120 sports club employees, including clubs' manager, employees and coaches located in Sanandaj, Iran. We surveyed employees at 45 clubs using a purposive technique. Data were collected using a paper-based survey distributed in January 2020. Out of the 140 questionnaires distributed, 120 were returned completed, giving a response rate of $85.71 \%$.

The sample size has a power prediction of 0.9 based on SPSS Sample Power. The sample size recommendations in PLS-SEM are based on OLS regression properties. With a sample size of 120, we would have a significance level of 0.05 and a statistical strength of 0.90 , indicating the equilibrium risk of type II error trading (false-negative results) and resource needs.
Mediating role of market orientation

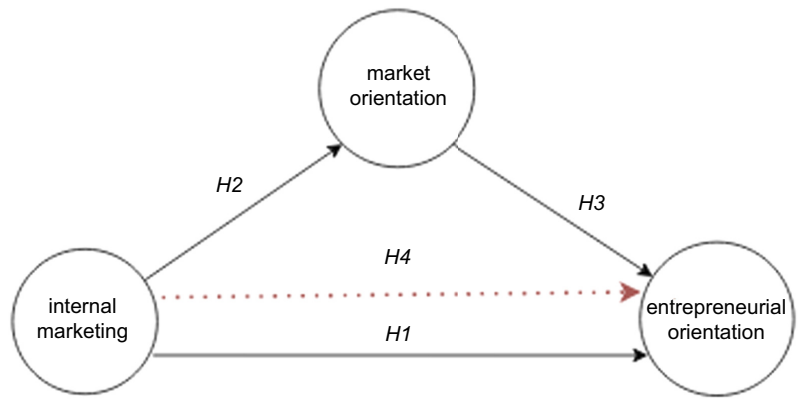

Figure 1. 
NEJE

25,2

The independent variable assessing internal marketing was measured using the X item scale developed by Lings and Greenley $(2009,2010)$. The mediation variable, market orientation, was measured using the X item scale developed by Jaworski and Kohli (1993). The dependent variable was the Entrepreneurial Orientation Questionnaire, measured using the X item scale developed by Hughes and Morgan (2007). All questions were designed using a 5-point Likert scale from very low to very high, and this form of measurement has been used in the previous literature (Lings and Greenley, 2009, 2010; Jaworski and Kohli, 1993; Hughes and Morgan, 2007). Table 1 lists all the items used.

\section{Sample characteristics}

We surveyed 45 clubs and asked each club manager to complete this and other employees and coaches. We distributed 140 surveys, and 120 of these were completed and returned. The demographic characteristics of subjects in Table 2 indicate that 77 respondents $(64.2 \%)$ are male, and $43(35.8 \%)$ are female. All respondents were educated beyond high school, which is reflective of the government requirements for people working in this sector. There were eight who had a diploma (6.66\%), 20 had Associate Degree $(16.7 \%), 74$ respondents had a bachelor degree $(61.64 \%)$, and 18 had either masters or $\mathrm{PhDs}(15.0 \%)$. The respondents also had extensive work experience, with $61 \%$ (i.e. 74 ) having more than 10 years' experience, $28.3 \%$ (i.e. 34) having between 6-10 years' experience, and only $10.0 \%$ having five years or less experience.

\section{Results}

Data were manually entered into a data file and then screened using SPSS25 before it was converted to CSV format and transferred to Smart PLS3 (Hair et al., 2019). PLS-SEM3 was used to determine the validity of the three constructs in the model (Hair et al., 2019). The factor loadings Cronbach's alpha $(\alpha)$, composite reliability (CR), and average variance extracted (AVE) were all assessed. Cronbach's alpha and CR assessed the degree to which the construct indicators indicate the latent construct, and thus the constructs are valid. The AVE represents the overall amount of variance in the indicators accounted for by the latent construct. According to (Hair et al., 2019), a Cronbach's alpha and CR value of 0.70 or more is considered acceptable for internal consistency measures and the three measures Cronbach's alpha values were from 0.74 to 0.88 , with $\mathrm{CR}$ values range The AVE for the three constructs varied from 0.40 to 0.54 , convergence validity is also established (Fornell and Larcer, 1981) (see Table 1).

The discriminant validity was assessed using the HTMT Henseler et al. (2015). As is reported in a lower diagonal in Table 3 , these are all below the criterion value of 0.85 . Thus, the divergent validity of the three constructs is acceptable. The correlation coefficients are presented in the upper diagonal of Table 3.

The coefficient of determination $(R 2)$ shows the effect of an independent variable on a dependent variable. $R 2$ values of $0.25,0.75$ and 0.50 (see Table 4) are considered substantial, moderate and weak, based on classifications within the methodological literature (Hair et al., 2019). The Stone-Geisser's $Q 2$ value was examined to ensure the predictive relevance of the structural model (Hair et al., 2019), the values of $Q 2$ must be greater than zero, which is the case for the variables in this study.

We next examined the effect size ( 2 ) of all independent variables towards the dependent variable's $R 2$ values (see Table 5). In structural models, the value of $f 2$ suggests variations in $R 2$ values caused by independent variables (Hair et al., 2017). Based on Hair et al. (2017), the effect size for the various relationships can be classified as small (0.02), medium (0.15) and large (0.35). 


\begin{tabular}{|c|c|c|c|c|c|}
\hline Factors and items & $\lambda$ & $\alpha$ & $\mathrm{CR}$ & AVE & Source \\
\hline IM & & 0.880 & 0.903 & 0.511 & \multirow{10}{*}{$\begin{array}{l}\text { Lings and } \\
\text { Greenley }(2009 \text {, } \\
\text { 2010) }\end{array}$} \\
\hline $\begin{array}{l}\text { This club notices the personnel's requirements } \\
\text { thoroughly }\end{array}$ & 0.749 & & & & \\
\hline $\begin{array}{l}\text { In this club, new programs are conducted well in the } \\
\text { sports fields }\end{array}$ & 0.696 & & & & \\
\hline $\begin{array}{l}\text { In this club, the most important part of attracting } \\
\text { customers is their features in accordance with their } \\
\text { needs }\end{array}$ & 0.723 & & & & \\
\hline $\begin{array}{l}\text { In this club, the manager spends adequate time } \\
\text { thinking about career problems in the club and the } \\
\text { performance of the coaches }\end{array}$ & 0.657 & & & & \\
\hline $\begin{array}{l}\text { In this club, the coaches constantly speak to one } \\
\text { another about carrying the plans out }\end{array}$ & 0.620 & & & & \\
\hline $\begin{array}{l}\text { In this club, I have entire knowledge about my } \\
\text { responsibilities }\end{array}$ & 0.658 & & & & \\
\hline $\begin{array}{l}\text { In this club, the coaches are encouraged owing to the } \\
\text { conduction and durability of the customer }\end{array}$ & 0.775 & & & & \\
\hline $\begin{array}{l}\text { In this club, the management efficiently lends us the } \\
\text { required support }\end{array}$ & 0.720 & & & & \\
\hline $\begin{array}{l}\text { In this club, new training methods in doing activities } \\
\text { are carried out }\end{array}$ & 0.815 & & & & \\
\hline MO & & 0.740 & 0.817 & 0.401 & \multirow{9}{*}{$\begin{array}{l}\text { Jaworski and } \\
\text { Kohli (1993) }\end{array}$} \\
\hline $\begin{array}{l}\text { In this club, we have some appointments with } \\
\text { customers to introduce the club more effectively }\end{array}$ & 0.461 & & & & \\
\hline $\begin{array}{l}\text { In this club, we engage in analyzing the competitors } \\
\text { with the same condition as us }\end{array}$ & 0.518 & & & & \\
\hline $\begin{array}{l}\text { In this club, the level of customers' satisfaction is } \\
\text { annually reported to fellow workers }\end{array}$ & 0.798 & & & & \\
\hline $\begin{array}{l}\text { In this club, short-term meetings are held in relation to } \\
\text { customer needs }\end{array}$ & 0.424 & & & & \\
\hline $\begin{array}{l}\text { In this club, a number of discussions and negotiations } \\
\text { are conducted with coaches and initiators concerning } \\
\text { customers' future needs }\end{array}$ & 0.731 & & & & \\
\hline The club annually attempts to present a new program & 0.670 & & & & \\
\hline $\begin{array}{l}\text { In this club, amendatory actions are uninterruptedly } \\
\text { performed toward customer's behavior and speech }\end{array}$ & 0.725 & & & & \\
\hline & & 0.788 & 0.855 & 0.541 & \\
\hline $\begin{array}{l}\text { In this club, we usually analyze new ideas and deal } \\
\text { with them operationally }\end{array}$ & 0.728 & & & & \multirow[t]{5}{*}{$\begin{array}{l}\text { Hughes and } \\
\text { Morgan (2007) }\end{array}$} \\
\hline $\begin{array}{l}\text { In this club, we search for creative methods for } \\
\text { performance and innovation }\end{array}$ & 0.785 & & & & \\
\hline $\begin{array}{l}\text { In this club, we properly recognize opportunities in } \\
\text { order to attract customers }\end{array}$ & 0.730 & & & & \\
\hline $\begin{array}{l}\text { In this club, we perform well against our other } \\
\text { competitors }\end{array}$ & 0.706 & & & & \\
\hline $\begin{array}{l}\text { In this club, our coaches have sufficient independence } \\
\text { in training and operation }\end{array}$ & 0.728 & & & & \\
\hline
\end{tabular}

Note(s): $\lambda=$ Outer Loading. $\alpha=$ Cronbach's Alpha. $\mathrm{CR}=$ Composite Reliability. $\mathrm{AVE}=$ Average Variance Extracted needs

thinking about career problems in the club and the performance of the coaches another about carrying the plans out

In this club, I have entire knowledge about my

In this club, the coaches are encouraged owing to the conduction and durability of the custome required support

In this club, new training methods in doing activities $\mathrm{MO}$

In this club, customers to introduce the club more effectively In this club, we engage in analyzing the competitors In this club, the level of customers' satisfaction is annually reported to fellow workers customer needs customers' future needs performed toward customer's behavior and speech with them operationally performance and innovation In this club, we properly recognize opportunities in order to attract customers competitors

In this club, our coaches have sufficient independence
Mediating role of market orientation

111 and measure

The SRMR is a model fit measure defined as the root mean square discrepancy between the observed correlations and the model-implied correlations. In CB-SEM, an SRMR value below 0.08 indicates a good fit, but no threshold value has been introduced in a PLS-SEM context (Hair et al., 2017). Henseler et al. (2015) identified this is a suitable criterion for PLS-SEM, 
NEJE

25,2

112

which is used to assess whether the model appropriately fits the data. According to Hair et al. (2017), SRMR can examine the model fit for testing the hypotheses and according to $\mathrm{Hu}$ and Bentler (1998), in the conservative mode, values less than 0.1 are suitable for model fit. The calculated value for this study was 0.1 , which confirmed the suitability of the model.

Measuring the intensity of the mediating effect

We use the VAF statistic to determine the mediation effect's intensity (Iacobucci and Duhachek, 2003). The measurement of this statistic is a value between 0 and 1 . A value less than 0.2 indicates there is no mediating effect; a value of $0.2-0.8$ has a partial mediation effect, and a value above 0.8 and above has a full mediation effect (Hair et al., 2014). To measure this statistic, we use the following formula.

$$
\mathrm{VAF}=\frac{a \times b}{(a \times b)+c}=\frac{0.578 * 0.433}{(0.578 * 0.433)+0.283}=0.469
$$

Table 6 shows the direct impact of internal marketing on market orientation and entrepreneurship development and the indirect effect (see Figure 2).

Table 2.

Demographic characteristics of subjects

\begin{tabular}{|ccc|cll|}
\hline Gender & & & Education & & \\
Male & 77 & $64.2 \%$ & Diploma & 8 & $6.7 \%$ \\
Female & 43 & $35.8 \%$ & Associate & 20 & $16.7 \%$ \\
Work Experience & & & BS & 74 & $61.4 \%$ \\
> 5 Years & 12 & $10.0 \%$ & Master/PhD & 18 & $15.0 \%$ \\
6-10 years & 34 & $28.4 \%$ & & & \\
10+ Years & 74 & $61.7 \%$ & & & \\
\hline
\end{tabular}

Table 3.

Correlation (top diagonal) and HTMT (lower diagonal)

\begin{tabular}{lccc}
\hline LV & EO & IM & MO \\
\hline EO & 0.735 & 0.533 & 0.596 \\
IM & 0.621 & 0.716 & 0.578 \\
MO & 0.746 & 0.691 & 0.633
\end{tabular}

Note(s): The square root diameter of the mean variance is extracted

\begin{tabular}{lccccccc}
\hline LV & $R$ square & $R$ square adjusted & Threshold & LV & $Q 2$ & Threshold & Source \\
\hline EO & 0.409 & 0.399 & $0.25 ; 0.5 ; 0.75$ & EO & 0.196 & $0.02 ; 0.15 ; 0.35$ & Hair et al. (2019) \\
MO & 0.334 & 0.329 & & MO & 0.113 & &
\end{tabular}

Table 4.

$R$ square and $Q 2$ Stone-

Geisser's

\begin{tabular}{lccc}
\hline LV & $F$-square & Threshold & Source \\
\hline $\mathrm{IM} \rightarrow \mathrm{EO}$ & 0.09 & $0.02 ; 0.15 ; 0.35$ & Hair et al. $(2019)$ \\
$\mathrm{MO} \rightarrow \mathrm{EO}$ & 0.211 & & \\
$\mathrm{IM} \rightarrow \mathrm{MO}$ & 0.502 & & \\
\hline
\end{tabular}




\section{Discussions}

In this study, we examined the role of internal marketing in market orientation and entrepreneurship development in sports clubs in Sanandaj, Iran. The hypothesis assesses the effect of internal marketing on the development of entrepreneurial orientation (H1). The coefficient has a $t$-value of 8.83 and has a statistically significant positive relationship. Based on the beta coefficient $\beta$, the internal marketing variable predicts $0.54 \%$ of the changes in entrepreneurial orientation. The result identify that internal marketing plays a significant role in the market orientation of organizations. The result is consistent with the work of (Modi and Sahi, 2017) and (Lings and Greenley, 2010). Sports clubs' internal marketing improves the organization's competitiveness and enhances competencies by influencing and motivating employees to be more entrepreneurial. Thus, higher internal marketing levels result in more entrepreneurial orientation, as employees are motivated to make the organizations successful. Therefore, organizations should pay attention to the importance of internal marketing to encourage new ideas generation, enhance performance and innovation, recognize opportunities, and ensure sufficient independence in the clubs' training and operation.

This hypothesis's results are consistent with past researchers' findings (Basirat et al., 2015; Jalilvand et al., 2019; Jin and Cho, 2018; Yadav and Bansal, 2020). As Basirat et al. (2015) have stated, internal marketing effectively affects the organization's employees' entrepreneurial tendencies and tendencies.

The second hypothesis is that internal marketing positively impacts market orientation. This is supported as the $t$-value is 8.98. Based on the $\beta$-beta coefficient, the internal marketing variable predicts $0.59 \%$ of the changes in the market orientation variable. This is consistent with the work of Bouranta et al. (2005) and Kyriazopoulos et al. (2007), who also found that internal marketing positively affects market orientation. The result indicated that more internal marking results in more market orientation. This may arise because more internal marketing makes employees more satisfied, and therefore they become more marketorientated. In private sports clubs, employees are in direct contact with customers. Thus, adapting and responding to employees' needs and demands is critical to customers'

\begin{tabular}{|c|c|c|c|c|c|c|c|}
\hline & Direct effects & $\beta$ & SD & $t$-value & $p$-values & Decision & \\
\hline $\mathrm{H} 1$ & $\mathrm{IM} \rightarrow \mathrm{EO}$ & 0.283 & 0.077 & 3.681 & 0.000 & Supported & \\
\hline $\mathrm{H} 2$ & $\mathrm{IM} \rightarrow \mathrm{MO}$ & 0.578 & 0.079 & 7.340 & 0.000 & Supported & \\
\hline H3 & $\begin{array}{l}\mathrm{MO} \rightarrow . \mathrm{O} \\
\text { Indirect Effects }\end{array}$ & 0.433 & 0.096 & 4.527 & 0.000 & $\begin{array}{l}\text { Supported } \\
\text { Mediation }\end{array}$ & Table 6. \\
\hline $\mathrm{H} 4$ & $\mathrm{I} . \mathrm{M} \rightarrow \mathrm{M} . \mathrm{O} \rightarrow \mathrm{E} . \mathrm{O}$ & 0.250 & 0.072 & 3.469 & 0.001 & Supported & Path coefficients model \\
\hline
\end{tabular}

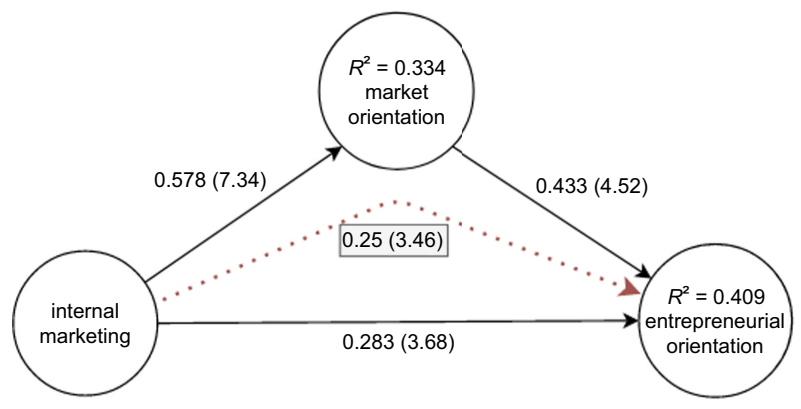

Figure 2.

Results of structural equation modeling for $\mathrm{H} 1$ to $\mathrm{H} 4$ 
NEJE

25,2

satisfaction. Lings and Greenley (2009) also found a strong relationship between internal marketing, employee motivation, and external marketing success (market orientation, financial performance, and customer satisfaction). The result is also in line with Grönroos and Helle (2010), who suggests that while market orientation and internal marketing are distinct, they are interrelated and potentially reflect a broad view of marketing philosophy. The results of this hypothesis are also consistent with the findings of Gellatly et al. (2020), Jin et al. (2018) and Salehzadeh et al. (2017).

The third hypothesis examined the effect of market orientation on the development of entrepreneurial orientation. It was significant with a $t$-value of 8.4 and a beta $\beta$ indicating that the market orientation variable predicts $0.62 \%$ of the changes in the entrepreneurial orientation. Thus the more market-oriented the clubs, the more entrepreneurial oriented they are. This positive relationship has been found by Faroque et al. (2021), Montiel-Campos (2018), Morgan and Anokhin (2020) and Octavia et al. (2020). Additionally, companies that combine market orientation with entrepreneurial development perform better than those did not (Atuahene-Gima and Ko, 2001). Understanding customers' behavior and needs in the future is an important prerequisite for a successful organization's strategic direction in a competitive environment in which market-oriented organizations can gain their share of competition between competitors. In addition, due to the high level of complexity in customer behavior and paying attention to external customers, internal customers who are employees of the organization should not be neglected. Employees are also required to have the enthusiasm to follow this approach, and only then can the organization create value for customers while engaging in entrepreneurial oriented behaviors. Thus sports clubs are more entrepreneurially when they are market focused.

The fourth hypothesis suggested that market orientation mediates the relationship between internal marketing and entrepreneurial orientation. The mediation analysis indicates an indirect path coefficient of 0.25 and a $t$-value of 3.71. This suggests that there is a statistically significant mediation effect. Internal marketing predicted $0.28 \%$ of changes in entrepreneurial orientation development. Internal marketing also predicted changes in market orientation by $0.57 \%$. Significance coefficients above 1.96 confirm the statistical significance of these relationships. The results showed that market orientation positively mediates the relationship between internal marketing and entrepreneurial orientation, with an indirect path coefficient of 0.25 . In addition, the $Q 2$ value of the structure in the market orientation and entrepreneurial tendency was calculated to be 0.11 and 0.19 , which demonstrated the strong predictive power of the model regarding these structures and the proper fit of the structural research model. Sports clubs can combine their internal marketing with market orientation, increasing the development of entrepreneurial orientation. Focusing on customers and competitors, market orientation obtains and disseminates the information obtained from them within the organization, thus promoting its entrepreneurial level. Market orientation focuses on the outside of the organization and has an outside-in approach. One of the essential ways to achieve entrepreneurial orientation is achieved through market orientation, using internal marketing. Market orientation in the organization will lead to entrepreneurial orientation by creating appropriate behaviors and market opportunities. Thus, sports organizations should adopt the necessary mechanisms to improve their market orientation. This includes appropriate strategies to discover and apply knowledge, maintain and enhance their position in existing markets, and identify opportunities to reach new markets (Ekhlassi et al., 2018). Focusing on internal marketing improves customer relationships by emphasizing training and motivating employees. Market orientation also has a positive and significant effect on entrepreneurial development. Therefore, clubs should pay attention to the market and use the market's information in formulating their strategies. The results of this finding are consistent with the results of Faroque et al. (2021), GonzálezBenito et al. (2009), Grönroos and Helle (2010), Montiel-Campos (2018), Octavia et al. (2020). 


\section{Conclusion}

Internal marketing is one strategy that can be used to enhance market orientation in private sports clubs. Related studies show that internal marketing activities rewards employees and improves their motivation. In general, it can be said that the implementation of internal marketing in sports clubs enhances these clubs capabilities ensuring they satisfy the internal staff, which leads to customer satisfaction and improved entrepreneurial orientation. Market orientation can lead to product and process innovation by responding to customers' expressed needs, which is an essential entrepreneurial orientation component. The research results show that internal marketing positively and significantly affects market orientation and entrepreneurial orientation in sports clubs. According to this research, by valuing the employees within the organization and satisfying their needs (i.e. using internal marketing), firms can increase market orientation to be motivated. Internal marketing cause's employees to be motivated and successful in entrepreneurship.

This research contributes to the extant literature in several ways. First, it provides evidence facilitating a better understanding of the relationship between internal marketing on entrepreneurial and market orientation in a sporting club context. Second, it provides evidence that facilitates a better understanding of the relationship between market orientation and entrepreneurial orientation. Third, considering the empirical context in which the analysis was conducted, at the intersection between market orientation as a mediator of internal marketing and the development of entrepreneurial orientation, this paper provides empirical evidence of the relationship and in-depth information on entrepreneurs in the sports field. Further, we have validated that these relationships apply in the sporting club context within the collectivist country. This highlights the generalizability of the results, both globally and across business contexts. As such, it makes a significant contribution to the current debate on lifestyle entrepreneurs and how they can enhance entrepreneurial activities by motivating internal staff.

\section{Suggestions for future research}

According to the present research results, future research seems necessary to identify intervening or moderating variables. The role of organizational performance and employee commitment could be integrated into future models. It is suggested that examining the size of the club might impact its market orientation. The role of club size in entrepreneurial orientation development might be necessary. As club size increases, it may be harder to communicate with all staff effectively. This research was undertaken in a developing country and may not be generalizable to other developing or developed countries, although the fact that relationships have been found in other countries suggests some generalizability. One might also examine whether these relationships apply in other high touch services. One might anticipate this to be the case, as such services require a better understanding of customer's and frequently have highlight specialized offerings. In addition, future research should also consider other variables that might influence entrepreneurial orientation. This provides a better understanding of the specific factors that affect an entrepreneurial orientation, which benefits both future researchers and practitioners in structuring the theory and recognizing the most influential factors of a sports club's entrepreneurial orientation. This research supported a more integrated and comprehensive theory of sports cub entrepreneurial orientation and thus advances the research in this domain.

\section{Limitations of the study}

This research is cross-sectional, and this makes it difficult to conclude the relationships between models. Another limitation of the sample size. Nonetheless, the researchers used a variance-based approach to assess the model, which overcomes these limitations. Lastly, the present research results can be generalized to private sports clubs in Sanandaj, and if necessary and generalized to other organizations in other countries should be done cautiously.
Mediating role of market orientation 
NEJE

25,2

\section{Note}

1. Deputy Minister of Youth Affairs of the Ministry Sports Iran.

\section{References}

Acosta, A.S., Crespo, Á.H. and Agudo, J.C. (2018), "Effect of market orientation, network capability and entrepreneurial orientation on international performance of small and medium enterprises (SMEs)", International Business Review, Vol. 27 No. 6, pp. 1128-1140.

Agti, D. and Louafi, K. (2019), "Effect of internal market orientation on organizational commitment: applied study at Algerian hotels", Roa Iktissadia Review, Vol. 9 No. 1, pp. 101-112.

Ahmed, P.K. and Rafiq, M. (2003), "Internal marketing issues and challenges", European Journal of Marketing, Vol. 37, pp. 1177-1186.

Al-Hawary, S.I.S., Al-Qudah, K., Abutayeh, P., Abutayeh, S. and Al-Zyadat, D.Y. (2013), "The impact of internal marketing on employee's job satisfaction of commercial banks in Jordan", Interdisciplinary Journal of Contemporary Research in Business, Vol. 4 No. 9, pp. 811-826.

Ali, G.A., Hilman, H. and Gorondutse, A.H. (2020), "Effect of entrepreneurial orientation, market orientation and total quality management on performance", Benchmarking: An International Journal, Vol. 27 No. 4, pp. 1503-1531.

Atuahene-Gima, K. and Ko, A. (2001), "An empirical investigation of the effect of market orientation and entrepreneurship orientation alignment on product innovation", Organization Science, Vol. 12 No. 1, pp. 54-74.

Awwad, M.S. and Agti, D.A.M. (2011), "The impact of internal marketing on commercial banks' market orientation”, International Journal of Bank Marketing, Vol. 29 No. 4, pp. 308-332.

Ball, S. (2005), "The importance of entrepreneurship to hospitality, leisure, sport and tourism", Hospitality, Leisure, Sport and Tourism Network, Vol. 1 No. 1, pp. 1-14.

Basirat, M., Imani, S., Zanejhad, M. and Dehghan Najmabadi, A. (2015), "Evaluating the mediatory effect of entrepreneurial orientation on the relationship between internal marketing and organizational commitment (case study: headquarter offices of aghajari oil and gas operating company)", The Journal of Productivity Management, Vol. 9 No. 1(32), pp. 147-170.

Bouranta, N., Mavridoglou, G. and Kyriazopoulos, P. (2005), "The impact of internal marketing to market orientation concept and their effects to bank performance", Operational Research, Vol. 5 No. 2, pp. 349-362.

Chen, H.L. and Hsu, C.H. (2013), "Entrepreneurial orientation and firm performance in non-profit service organizations: contingent effect of market orientation", The Service Industries Journal, Vol. 33 No. 5, pp. 445-466.

Chiu, W., Won, D. and Bae, J.-s. (2019), "Internal marketing, organizational commitment, and job performance in sport and leisure services", Sport, Business and Management: An International Journal, Vol. 10 No. 2, pp. 105-123.

Chuang, S.-H. (2018), "Facilitating the chain of market orientation to value co-creation: the mediating role of e-marketing adoption", Journal of Destination Marketing and Management, Vol. 7, pp. 39-49.

Cooper, J. and Cronin, J.J. (2000), "Internal marketing: a competitive strategy for the long-term care industry”, Journal of Business Research, Vol. 48 No. 3, pp. 177-181.

De Bruin, L., Roberts-Lombard, M. and De Meyer-Heydenrych, C. (2021), "Internal marketing, service quality and perceived customer satisfaction: an Islamic banking perspective", Journal of Islamic Marketing, Vol. 12 No. 1, pp. 199-224, doi: 10.1108/JIMA-09-2019-0185.

Ekhlassi, A., Seyyedamiri, N. and Hendijani Fard, M. (2018), "The role of internal market orientation in developing entrepreneurial orientation: the case of internet service providers (ISPs) in Tehran", New Marketing Research Journal, Vol. 8 No. 1, pp. 97-116, doi: 10.22108/nmrj.2018.103958.1249. 
Eric, A.B. (2017), "An empirical assessment of the extent of practice of external, internal and interactive marketing: the case of financial service firms in Ghana”, IMPACT: International Journal of Research in Business Management, Vol. 5 No. 11, pp. 121-130.

Ericsson, C. (2015), A Typology of Brand Orientation: Acase Study of Corporate Brand Management, (Unpublished master thesis), Lund's University.

Escamilla-Fajardo, P., Ratten, V. and Núñez-Pomar, J. (2020), Sport Entrepreneurship, Financial, Sporting and Social Performance: A Theoretical Framework Entrepreneurship as Empowerment: Knowledge Spillovers and Entrepreneurial Ecosystems, Emerald Publishing, pp. 63-80.

Fadda, N. (2020), "Entrepreneurial behaviours and managerial approach of lifestyle entrepreneurs in surf tourism: an exploratory study", Journal of Sport and Tourism, Vol. 24 No. 1, pp. 53-77.

Faroque, A.R., Mostafiz, M.I., Faruq, M.O. and Bashar, M.F.B. (2021), "Revisiting entrepreneurial capabilities and export market orientation: a multi-scale investigation in an emerging economy", International Journal of Emerging Markets, Vol. 16 No. 3, pp. 556-579, doi: 10.1108/ IJOEM-08-2019-0644.

Farrelly, F., Quester, P. and Clulow, V. (2008), "Exploring market orientation and satisfaction of partners in the sponsorship relationship", Australasian Marketing Journal, Vol. 16 No. 2, pp. 51-66.

Frisby, W. (2005), "The good, the bad, and the ugly: critical sport management research", Journal of Sport Management, Vol. 19 No. 1, pp. 1-12.

Gellatly, L., D’Alessandro, S. and Carter, L. (2020), "What can the university sector teach us about strategy? Support for strategy versus individual motivations to perform", Journal of Business Research, Vol. 112, pp. 320-330.

Ghorbani, M. and Safari, H. (2017), Start up and Management of Sport Club, Sport Sciences Research Institute, Tehran.

González-Benito, Ó., González-Benito, J. and Muñoz-Gallego, P.A. (2009), "Role of entrepreneurship and market orientation in firms' success", European Journal of Marketing, Vol. 43 Nos 3/4, pp. 500-522.

Grönroos, C. and Helle, P. (2010), “Adopting a service logic in manufacturing: conceptual foundation and metrics for mutual value creation”, Journal of Service Management, Vol. 21 No. 5, pp. 564-590.

Hair, J.F. Jr, Sarstedt, M., Hopkins, L. and Kuppelwieser, V.G. (2014), "Partial least squares structural equation modeling (PLS-SEM)", European Business Review, Vol. 26 No. 2, pp. 106-121.

Hair, J.F., Hult, G.T.M., Ringle, C.M., Sarstedt, M. and Thiele, K.O. (2017), "Mirror, mirror on the wall: a comparative evaluation of composite-based structural equation modeling methods", Journal of the Academy of Marketing Science, Vol. 45 No. 5, pp. 616-632.

Hair, J.F., Risher, J.J., Sarstedt, M. and Ringle, C.M. (2019), "When to use and how to report the results of PLS-SEM", European Business Review, Vol. 31 No. 1, pp. 2-24.

Hardy, S. and Pope, S. (1996), "Entrepreneurs, organizations, and the sport marketplace", The New American Sport History, pp. 341-365, University of Illinois Press, Illinois.

Hemme, F., Morais, D.G., Bowers, M.T. and Todd, J.S. (2017), "Extending sport-based entrepreneurship theory through phenomenological inquiry”, Sport Management Review, Vol. 20 No. 1, pp. 92-104.

Henseler, J., Ringle, C.M. and Sarstedt, M. (2015), "A new criterion for assessing discriminant validity in variance-based structural equation modeling", Journal of the Academy of Marketing Science, Vol. 43 No. 1, pp. 115-135.

Herman, H., Hady, H. and Arafah, W. (2018), "The influence of market orientation and product innovation on the competitive advantage and its implication toward Small and Medium Enterprises (UKM) performance", International Journal of Science and Engineering Invention, Vol. 4 No. 08 , pp. 08-21.

Herrero, A., San Martín, H. and Collado, J. (2018), "Market orientation and SNS adoption for marketing purposes in hospitality microenterprises", Journal of Hospitality and Tourism Management, Vol. 34, pp. 30-40, doi: 10.1016/.j.smr.2020.02.001.
Mediating role of market orientation 
NEJE

25,2

Hu, L.T. and Bentler, P.M. (1998), "Fit indices in covariance structure modeling: sensitivity to underparameterized model misspecification”, Psychological Methods, Vol. 3 No. 4, p. 424.

Huang, Y.T. (2020), "Internal marketing and internal customer: a review, reconceptualization, and extension”, Journal of Relationship Marketing, Vol. 19 No. 3, pp. 165-181.

Huang, Y.-T. and Rundle-Thiele, S. (2015), "A holistic management tool for measuring internal marketing activities", Journal of Services Marketing, Vol. 29 Nos 6/7, pp. 571-584.

Hughes, M. and Morgan, R.E. (2007), "Deconstructing the relationship between entrepreneurial orientation and business performance at the embryonic stage of firm growth", Industrial Marketing Management, Vol. 36 No. 5, pp. 651-661.

Iacobucci, D. and Duhachek, A. (2003), "Mediation analysis-round table acr 2003”, Paper Presented at the Presentation at the Round Table of the ACR Conference, Toronto.

Ismail, M., Zainol, F.A., Daud, W.N.W., Rashid, N. and Afthanorhan, A. (2018), "Application of entrepreneurial marketing to the marketing mix: why it matters to SMEs in Malaysia?", International Journal of Academic Research in Business and Social Sciences, Vol. 8 No. 12, pp. 850-865.

Jakubiak, M. and Chrapowicki, P. (2018), "SMEs and determinants of their internationalization in Poland, Germany and Denmark", Problemy Zarzadzania, pp. 126-142, (1/2018 (73), t. 2).

Jalilvand, M.R., Vosta, L.N., Khalilakbar, R., Pool, J.K. and Tabaeeian, R.A. (2019), "The effects of internal marketing and entrepreneurial orientation on innovation in family businesses", Journal of the Knowledge Economy, Vol. 10 No. 1, pp. 1-16.

Jaworski, B.J. and Kohli, A.K. (1993), "Market orientation: antecedents and consequences", Journal of Marketing, Vol. 57 No. 3, pp. 53-70.

Jin, B. and Cho, H.J. (2018), "Examining the role of international entrepreneurial orientation, domestic market competition, and technological and marketing capabilities on SME's export performance", Journal of Business and Industrial Marketing, Vol. 33 No. 5, pp. 585-598.

Jin, B., Jung, S. and Jeong, S.W. (2018), "Dimensional effects of Korean SME's entrepreneurial orientation on internationalization and performance: the mediating role of marketing capability", International Entrepreneurship and Management Journal, Vol. 14 No. 1, pp. 195-215.

Kamboj, S. and Rahman, Z. (2017), "Market orientation, marketing capabilities and sustainable innovation", Management Research Review, Vol. 40 No. 6, pp. 698-724.

Kao, R.W. (1993), "Defining entrepreneurship: past, present and?", Creativity And Innovation Management, Vol. 2 No. 1, pp. 69-70.

Keating, M.A. and Olivares, M. (2007), "Human resource management practices in Irish high-Tech start-up firms", Irish Journal of Management, Vol. 28 No. 2, pp. 171-192.

Kirca, A.H., Jayachandran, S. and Bearden, W.O. (2005), "Market orientation: a meta-analytic review and assessment of its antecedents and impact on performance", Journal of Marketing, Vol. 69 No. 2, pp. 24-41.

Kohli, A.K. and Jaworski, B.J. (1990), "Market orientation: the construct, research propositions, and managerial implications", Journal of Marketing, Vol. 54 No. 2, pp. 1-18.

Kuratko, D.F., Hornsby, J.S. and Bishop, J.W. (2005), "Managers' corporate entrepreneurial actions and job satisfaction", The International Entrepreneurship and Management Journal, Vol. 1 No. 3, pp. 275-291.

Kushwaha, T. and Dubey, R. (2018), "Sales orientation and customer orientation: a review", Prestige International Journal of Management and Research, Vol. 10 No. 4, pp. 214-226.

Kyriazopoulos, P., Yannacopoulos, D., Spyridakos, A., Siskos, Y. and Grigoroudis, E. (2007), "Implementing internal marketing through employee's motivation", POMS 18th Annual Conference Dallas, Texas.

Lado, N., Duque, L.C. and Alvarez Bassi, D. (2013), "Current marketing practices and market orientation in the context of an emerging economy: the case of Uruguay", Journal of Small Business Management, Vol. 51 No. 4, pp. 602-616. 
Lam, S.K., Kraus, F. and Ahearne, M. (2010), "The diffusion of market orientation throughout the organization: a social learning theory perspective", Journal of Marketing, Vol. 74 No. 5, pp. 61-79.

Liao, S.H., Chang, W.J., Wu, C.C. and Katrichis, J.M. (2011), "A survey of market orientation research (1995-2008)”, Industrial Marketing Management, Vol. 40 No. 2, pp. 301-310.

Lings, I.N. and Greenley, G.E. (2009), "The impact of internal and external market orientations on firm performance", Journal of Strategic Marketing, Vol. 17 No. 1, pp. 41-53.

Lings, I.N. and Greenley, G.E. (2010), "Internal market orientation and market-oriented behaviours", Journal of Service Management, Vol. 21 No. 3, pp. 321-343.

Lumpkin, G.T. and Dess, G.G. (1996), "Clarifying the entrepreneurial orientation construct and linking it to performance", Academy of Management Review, Vol. 21 No. 1, pp. 135-172.

Ma, Y.J., Kim, M.J., Heo, J.S. and Jang, L.J. (2012), “The effects entrepreneurship and market orientation on social performance of social enterprise", Paper Presented at the Int Conf Econ Market Manager. IPEDR, Vol. 28, pp. 60-65.

Modi, P. and Sahi, G.K. (2017), "Toward a greater understanding of the market orientation and internal market orientation relationship", Journal of Strategic Marketing, Vol. 26 No. 6, pp. 1-18.

Mohamadkazemi, R., Zaffarian, R., khodayari, A. and Javadinia, M. (2014), "Identifying entrepreneurial business opportunities in sports industry with an IT approach", Journal of Entrepreneurship Development, Vol. 7 No. 1, pp. 95-112.

Mondali Zadeh, Z. (2019), "Determining the relationship of market orientation and brand orientation with sports clubs' performance”, Sport Management Studies, Vol. 10 No. 52, pp. 73-90.

Monteiro, A.P., Soares, A.M. and Rua, O.L. (2017), "Linking intangible resources and export performance", Baltic Journal of Management, Vol. 12 No. 3, pp. 329-347.

Montiel-Campos, H. (2018), "Entrepreneurial orientation and market orientation", Journal of Research in Marketing and Entrepreneurship, Vol. 20 No. 2, pp. 292-322.

Morgan, T. and Anokhin, S.A. (2020), "The joint impact of entrepreneurial orientation and market orientation in new product development: studying firm and environmental contingencies", Journal of Business Research, Vol. 113, pp. 129-138.

Narver, J.C. and Slater, S.F. (1990), "The effect of a market orientation on business profitability", Journal of Marketing, Vol. 54 No. 4, pp. 20-35.

Ng, M.D. (2009), Relationship Amongst Market Orientation, Service Quality, Firm Innovation and Fitness Enterprises' Performance in Kenya, Kenyatta University, (Unpublished thesis).

Octavia, A., Indrawijaya, S., Sriayudha, Y. and Hasbullah, H. (2020), "Impact on E-commerce adoption on entrepreneurial orientation and market orientation in business performance of SMEs", Asian Economic and Financial Review, Vol. 10 No. 5, p. 516.

Pearce, J.A., Fritz, D.A. and Davis, P.S. (2010), "Entrepreneurial orientation and the performance of religious congregations as predicted by rational choice theory", Entrepreneurship Theory and Practice, Vol. 34 No. 1, pp. 219-248.

Pitt, L., Caruana, A. and Berthon, P.R. (1996), "Market orientation and business performance: some European evidence", International Marketing Review, Vol. 13 No. 1, pp. 5-18.

Pittino, D., Visintin, F. and Lauto, G. (2017), "A configurational analysis of the antecedents of entrepreneurial orientation", European Management Journal, Vol. 35 No. 2, pp. 224-237.

Rafiq, M. and Ahmed, P.K. (2000), "Advances in the internal marketing concept: definition, synthesis and extension", Journal of Services Marketing, Vol. 14 No. 6, pp. 449-462.

Salehzadeh, R., Pool, J.K., Tabaeeian, R.A., Amani, M. and Mortazavi, M. (2017), "The impact of internal marketing and market orientation on performance: an empirical study in restaurant industry", Measuring Business Excellence, Vol. 21 No. 4, pp. 273-290.

Seyed Javadin, S.R., Barari, M. and Saatchian, V. (2014), "Relationship marketing in sport industry", Sport Management Studies, Vol. 6 No. 23, pp. 15-34.
Mediating role of market orientation 
NEJE

25,2

Spilling, O.R. (1996), "The entrepreneurial system: on entrepreneurship in the context of a megaevent”, Journal of Business Research, Vol. 36 No. 1, pp. 91-103.

Subramony, M., Segers, J., Chadwick, C. and Shyamsunder, A. (2018), "Leadership development practice bundles and organizational performance: the mediating role of human capital and social capital”, Journal of Business Research, Vol. 83, pp. 120-129.

Swartz, G.S. (1990), "Organizing to become market-driven: conference summary", Marketing Science Institute Conference, Boston, Massachusetts, September 13-14, 1990, Marketing Science Institute.

Tang, A.D., Chang, M.L., Wang, T.H. and Lai, C.H. (2020), "How to create genuine happiness for flight attendants: effects of internal marketing and work-family interface", Journal of Air Transport Management, Vol. 87 No. 1, 101860.

Tansuhaj, P., Randall, D. and McCullough, J. (1988), "A services marketing management model: integrating internal and external marketing functions", Journal of Services Marketing, Vol. 2 No. 1, pp. 31-38.

Tsai, Y. and Tang, T.W. (2008), "How to improve service quality: internal marketing as a determining factor", Total Quality Management, Vol. 19 No. 11, pp. 1117-1126.

Tsiotsou, H. (2010), "Delineating the effect of market orientation on services performance: a component-wise approach”, The Service Industries Journal, Vol. 30 No. 3, pp. 375-403.

Twomey, D.F. and Harris, D.L. (2000), "From strategy to corporate outcomes: aligning human resource management systems with entrepreneurial intent", International Journal of Commerce and Management, Vol. 10 Nos 3/4, pp. 43-55.

Vamplew, W. (2013), “Theories and typologies: a historical exploration of the sports club in Britain", The International Journal of the History of Sport, Vol. 30 No. 14, pp. 1569-1585.

Welch, M. and Jackson, P.R. (2007), "Rethinking internal communication: a stakeholder approach", Corporate communications: An international journal., Vol. 12 No. 2, pp. 177-198.

Yadav, A. and Bansal, S. (2020), "Viewing marketing through entrepreneurial mindset: a systematic review”, International Journal of Emerging Markets, Vol. 16 No. 2, pp. 133-153.

Yusuf, G.O., Sukati, I. and Andenyang, I. (2016), "Internal marketing practices and customer orientation of employees in Nigeria banking sector", International Review of Management and Marketing, Vol. 6 No. 4S, pp. 217-223.

Zhang, J., Li, H., Li, V., Xia, B. and Skitmore, M. (2020), "Internal relationships of market-oriented EFQM enablers in the Chinese construction industry", Engineering, Construction and Architectural Management, Vol. 28 No. 3, pp. 765-787.

Zheng-lun, W. (2008), "To enhance the running competitiveness of sport institutes with marketorientation and character exploration__ options on specialty adjustment in sport institutes", Journal of Nanjing Institute of Physical Education (Social Science), Vol. 3 No. 22, pp. 1-5.

\section{Further reading}

Frisk, V. (2017), Sales-Oriented Mindset in A Service-Oriented Environment:-Organizing Customer Service Operations for Higher Quality and Efficiency, (Unpublished thesis), UMEA University.

\section{Corresponding author}

Hossein Mansouri can be contacted at: hoseinmansouri66@gmail.com

For instructions on how to order reprints of this article, please visit our website:

www.emeraldgrouppublishing.com/licensing/reprints.htm

Or contact us for further details: permissions@emeraldinsight.com 